\title{
AIRBNB ON THE COSTA BLANCA. DIAGNOSIS AND PROPOSAL OF SOCIAL AND TOURIST INTEGRATION
}

\author{
IKER JIMENO MIRANDA, ANTONIO ALEDO TUR \& ARMANDO ORTUÑO PADILLA \\ Departamento de Sociología I y Departamento de Ingeniería Civil, Universidad de Alicante, España.
}

\begin{abstract}
This article explores the potential of the new peer-to-peer (P2P) platforms for tourist accommodation as a local development tool for the residential tourism oriented economies on the main Costa Blanca (Spain) municipalities. It analyzes the main characteristics of this phenomenon and its interaction with the residential tourism model. The ability of these platforms to offset the negative impacts of residential tourism is examined. The opportunities offered by P2P tourist accommodation platforms to favor a transition from a construction based economy to a residential one will be discussed in the conclusions.
\end{abstract}

Keywords: Airbnb, Costa Blanca, P2P platforms, Residential tourism, Sharing economy

\section{INTRODUCTION}

Online platforms such as Airbnb are changing the way of accessing tourist accommodation in Spain [1]. Its implementation has generated a series of impacts, due, among other reasons, to the newness of the phenomenon. The emergent nature of the phenomenon has caused a vacuum in the possible formulas of governance/management. Therefore, the situation calls for a rigorous analysis aimed at finding new governance/management proposals that work in the direction of maximizing the positive impacts of these platforms and minimizing their negative externalities in order to correctly integrate the phenomenon in the more encompassing economic dynamics of these tourist destinations.

A scientific approach to $\mathrm{P} 2 \mathrm{P}$ specialized in holiday accommodation requires taking into account the variability of the phenomenon when interacting with local structures. Residential tourism (RT), the tourism model par excellence on the Costa Blanca, is historically characterized by a quick and massive urban development that eventually left many municipalities on the Costa Blanca with a high stock of houses having a potential use as holiday homes [2]. With the arrival of the economic crisis and the bursting of the housing bubble, many of the municipalities that based their development on the construction and sale of holiday homes have suffered significant socioeconomic difficulties [3].

Can P2P tourist accommodation platforms help reduce the negative impacts generated by the RT model and become an instrument for local development? In order to answer our research question, the phenomenon of the new P2P vacation rentals platforms (2P-VR platforms) is described, the main characteristics of RT are discussed and, finally, the phenomenon of P2P-VR expansion on the Costa Blanca is analyzed by looking at the case study of two municipalities: Denia and Torrevieja.

The extraordinary progress that has taken place in the field of Information Technology (IT) in recent years, especially in regard to the internet and the development of its potential, has reconfigured the way of accessing information, of acquiring or offering goods and services, and, ultimately, the way of relating and communicating $[4,5]$.

$\mathrm{P} 2 \mathrm{P}$ platforms which are not intended to offer a specific product or service but basically seek to bridge the offer and demand of individuals following the peer-to-peer (P2P) dynamics 
[4], have recently proliferated. These P2P platforms take advantage of the reduction in transactions costs made possible by the use of the internet and the possibilities offered by the Web for establishing broad exchange networks $[6,7]$.

The emergence of P2P platforms has coincided with the birth of the Web 2.0 and the popularization of virtual social networks that offer a new means of communication and access to information [8]. These new platforms have incorporated some of the operational logic of social networks: they encourage, for instance, feedback between users and establish online rating systems as trust generators. This adopting of the interactional logics and modus operandi of social networks is undoubtedly one of the keys to their success [5].

P2P platforms cover the most diverse sectors. They have had a significant impact on the tourism sector and, more specifically, in the field of holiday accommodation [9, 10]. Airbnb, the pioneer company and current world leader in tourist accommodation through P2P platforms, has experienced extraordinary growth since its inception in the US in 2008. It began its international expansion very early and in 2010 it arrived in Spain, where it has shown robust growth in line with its general world trend.

A varied array of studies and estimations forecast the continued trend in the foreseeable future [11] and, therefore, confirm that it is a phenomenon that is here to stay [12]. This exceptional growth, the speed of expansion, the novelty of the phenomenon and the global dimension acquired have made this type of activity one of the most relevant socio-economic phenomena of recent years [7].

The activity carried out by the P2P-VR platforms has been classified within the broad label of the "Sharing economy" [8]. This concept is subject to great debate [13] since, in practice, significantly different activities and models of economic exchange are framed under this umbrella concept. At the same time, the emergence of the phenomenon and the rapidity of social change hinder its delimitation and definitive conceptualization [14, 15].

In the area of P2P-VR there is also a significant debate regarding its inclusion within the sharing economies category [15]. It is a debatable issue whether platforms such as Airbnb should be located within the P2P model, since the company charges commissions, both to the landlord and the customer, thus making the relationship a mediated transaction rather than an interaction between peers [13].

The absence of specific regulation for this activity is also a subject of discussion [5]. Critics of this model point out that the legal vacuum partially allows the success and expansion of these types of platforms [16]. In the Spanish case, the different levels of government are starting to correct this absence of regulation in a slow and gradual manner. Thus, in Spain there is a remarkable diversity of regulations and measures implemented by the Autonomous Communities (Regional governments) and municipalities [17].

A third point of debate revolves around the unequal distribution of negative and positive impacts caused by this phenomenon. The impacts are the result or the effect of an intervention, action, project or activity on a given area and a community [18]. Therefore, the impact is conditioned by: (a) the type of activity; (b) the characteristics of vulnerability or resilience of the area or the community; and (c) the context that filters the effects of the activity on the community and the area.

An evaluation of the impacts of P2P-VR platforms in tourist destinations requires their previous contextualization in order to understand the externalities they generate. Each municipality shows different characteristics at the socioeconomic, urban planning and tourism dimensions and, therefore, the morphology of impacts will depend on the socio-touristic context of the localities where P2P-VR are been implemented [7]. 


\section{METHODOLOGY}

After the initial description of the phenomenon of P2P-VR platforms, Airbnb activity is analyzed in the municipalities of Denia and Torrevieja (Costa Blanca, Spain). The choice of this platform as subject of analysis is based on its status as both a pioneer and the leader of the P2P tourism market worldwide $[5,7,10]$. The data analyzed in this paper have been obtained from AirDNA, a database specialized in the analysis of data from Airbnb for the use of investors, analysts, academics, etc.

The choice of Denia and Torrevieja is justified by the fact that they are two landmarks of the residential tourism model on the Costa Blanca. In the case of Torrevieja, with a resident population of 89,737 , the non-resident linked population (individuals that spend more than 14 nights per year in the city) amounts to 96,988 people, the largest of the medium-sized Spanish cities. These values are also very high in Denia: 42,635 residents and a linked population of 43,830 .

The analysis was carried out by our research team as follows: Firstly, we looked into the structural impacts of RT that can be potentially modified or alleviated through the integration of the P2P-VR platform model. Data were taken from the National Population and Housing Census and Urban Audit by the Spanish National Institute of Statistics (INE), the annual Report on Tourist Offer by the Valencian Tourism Agency, and the information portal ARGOS of the Valencian Regional Government (Generalitat Valenciana). Secondly, we present data regarding the Airbnb activity in the two selected municipalities, obtained from the specialized platform AirDNA. Based on this information, the potential of these platforms to reduce the structural impacts of the RT model is identified and analyzed, and the positive dynamics that could be generated by an efficient governance/management of the phenomenon are assessed.

\section{CASE STUDIES}

RT is the predominant tourism model on the Costa Blanca [19-21]. It is a based on urban development, mostly of an extensive spatial nature, and oriented to the real estate market of second or residential homes for holidaymakers and European retirees [22]. Its implementation on the Costa Blanca began in the seventies. From 1997, it went through a real estate bubble that burst in 2007 with dramatic damaging effects on the municipalities of this tourist region. RT generates a series of negative impacts that affect both the environment and landscape and the community in which it develops [23]. This paper states that these impacts can be modified or alleviated through P2P vacation rental strategies. The study cases of Denia and Torrevieja have allowed us to identify the following characteristics of the RT based economic model:

1.- A high degree of unoccupied homes. The real estate development favored by the RT model has generated a significant stock of unoccupied homes on the Costa Blanca [21]. In 2011, INE placed Torrevieja as the municipality within the Alicante province with the highest number of second homes $(62,585)$ and fourth largest Spanish population with second and vacant properties $(82,472)$. Only the three cities with the largest population in the country Madrid, Barcelona and Valencia - have more houses of this type. The tables below show the data of main, second and vacant dwellings in the municipalities of Denia and Torrevieja.

This significant number of second and vacant dwellings leads to the under-utilization of the urban infrastructure and services that have been theoretically designed to cater for the potential needs of a much larger population. In the same way, the large number of vacant properties implies heavy maintenance costs for the households who invested in this product 
Table 1: Denia. Tipology of dwellings.

\begin{tabular}{|c|c|c|c|c|c|c|c|c|c|}
\hline \multirow[b]{2}{*}{ Denia } & \multirow{2}{*}{$\begin{array}{l}\text { Total } \\
\text { dwellings }\end{array}$} & \multicolumn{2}{|c|}{ Main homes } & \multicolumn{2}{|c|}{ Second homes } & \multicolumn{2}{|c|}{ Vacant dwellings } & \multicolumn{2}{|c|}{ Others } \\
\hline & & $\mathrm{N}^{\mathrm{o}}$ & $\%$ & $\mathrm{~N}^{\mathrm{o}}$ & $\%$ & $\mathrm{~N}^{\mathrm{o}}$ & $\%$ & $\mathrm{~N}^{\mathrm{o}}$ & $\%$ \\
\hline 2011 & 43.348 & 17.248 & 39,8 & 12.507 & 28,8 & 13.587 & 31,3 & 6 & 0,0 \\
\hline 2001 & 35.341 & 12.308 & 34,8 & 19.066 & 53,9 & 3.824 & 10,8 & 143 & 0,40 \\
\hline
\end{tabular}

(Source: Authors, based on INE data)

Table 2: Torrevieja. Tipology of housing.

\begin{tabular}{|c|c|c|c|c|c|c|c|c|c|}
\hline \multirow[b]{2}{*}{ Torrevieja } & \multirow{2}{*}{$\begin{array}{l}\text { Total } \\
\text { dwellings }\end{array}$} & \multicolumn{2}{|c|}{ Main homes } & \multicolumn{2}{|c|}{ Second homes } & \multicolumn{2}{|c|}{ Vacant dwellings } & \multicolumn{2}{|c|}{ Others } \\
\hline & & $\mathrm{N}^{\mathrm{o}}$ & $\%$ & $\mathrm{~N}^{\mathrm{o}}$ & $\%$ & $\mathrm{~N}^{\mathrm{o}}$ & $\%$ & $\mathrm{~N}^{\mathrm{o}}$ & $\%$ \\
\hline 2011 & 122.338 & 39.855 & 32,5 & 62.585 & 51,1 & 19.887 & 16,2 & 11 & 0,0 \\
\hline 2001 & 102.363 & 21.565 & 21 & 61.745 & 60,3 & 18.898 & 18,4 & 155 & 0,15 \\
\hline
\end{tabular}

(Source: Authors, based on INE data)

and who, on top of that and due to the crisis, have seen the financial value of their investment drop dramatically.

2.- A quantitatively relevant segment of this type of properties does not officially enter the tourist market. Therefore, the commercialization of these assets and the tourist potential of the municipalities and their ability to generate positive impacts on local economies are highly undermined. The data referring to the evolution of holiday homes and the estimation of Dwellings for Potential Tourist Use (DPTU) in the localities under study is presented below. The DPTU category includes second and vacant dwellings potentially available as holiday homes, whether during the whole year or in some period of it [24]. Specifically, the formula used in the Tourism Spaces Plan by the Valencian regional government, 2007, is applied, whereby $100 \%$ of second dwellings and $50 \%$ of vacant ones are considered for the calculation, the final tourist places being obtained by multiplying this number by 3.5

These data show the great potential tourist dwellings feature in RT municipalities and the scarce use that is made of them through the official rental mechanisms. The DPTU's are particularly relevant in view of the continuous increase of tourists' arrivals that Spain has been

Table 3: Denia. Registered/regulated apartments and DPTU places.

\begin{tabular}{lllll}
\hline Denia & $N^{\text {o dwellings }}$ & N of places $^{\text {o }}$ & DPTU & Places DPTU \\
\hline 2016 & 2.738 & 13.296 & 19.300 & 73.340 \\
2011 & 2.013 & 9.890 & 19.300 & 73.340 \\
2001 & 1.979 & 8.264 & 20.978 & 73.423 \\
\hline
\end{tabular}

(Source: Authors, based on data from the Valencian Tourism Agency (Agencia Valenciana de Turismo) and National Institute of Statistics (INE)) 
Table 4: Torrevieja. Registered apartments and places.

\begin{tabular}{lllll}
\hline Torrevieja & $\mathrm{N}^{\mathrm{o}}$ dwellings & $\mathrm{N}^{\mathrm{o}}$ of places & DPTU & Places DPTU \\
\hline 2016 & 1.563 & 6.716 & 72.528 & 253.848 \\
2011 & 398 & 1.776 & 72.528 & 253.848 \\
2001 & 580 & 2.323 & 71.203 & 249.210
\end{tabular}

(Source: Authors, based on data from the Valencian Tourism Agency (Agencia Valenciana de Turismo) and National Institute of Statistics (INE))

experiencing in recent years. In 2017, a total of 82 million tourists arrived in Spain, which represents an increase of $8.9 \%$ compared to 2016, according to INE.

3.- High seasonality rate. A high percentage of tourist-residential homes users occupy these dwellings exclusively during the summer months [21]. A large number of properties in RT municipalities remain vacant for a good part of the year. As a result, unemployment figures are very high in the low season. For example, according to SERVEF data, in January 2017 there were a total of 8,719 job seekers in Torrevieja, while in July of that same year the number had come down to 6,895 , which represents a decrease of $21 \%$. The following chart shows the occupancy rate month by month in the registered/regulated properties of the Denia municipality and exemplifies the high seasonal concentration characterizing this tourism model:

The difference between the month featuring the highest occupancy rate and the month with the lowest is clear evidence of the strong seasonality of the model. While in the month of June 2017 there was an occupancy rate of $78.22 \%$, in January 2016 the occupation was only an insignificant $0.52 \%$.

4.- High dependence of employment in the construction sector. The construction sector has concentrated a large part of the economic activity and economic development has historically depended too much on real estate activity along the Costa Blanca [3]. As a result, the development of other productive sectors has been hindered and even almost totally precluded. With the bursting of the housing bubble in 2007 and the subsequent slowdown in the construction sector, RT municipalities have suffered significant impacts, particularly in the labor market [19]. The unemployment rate has grown significantly and family incomes have plummeted alarmingly.

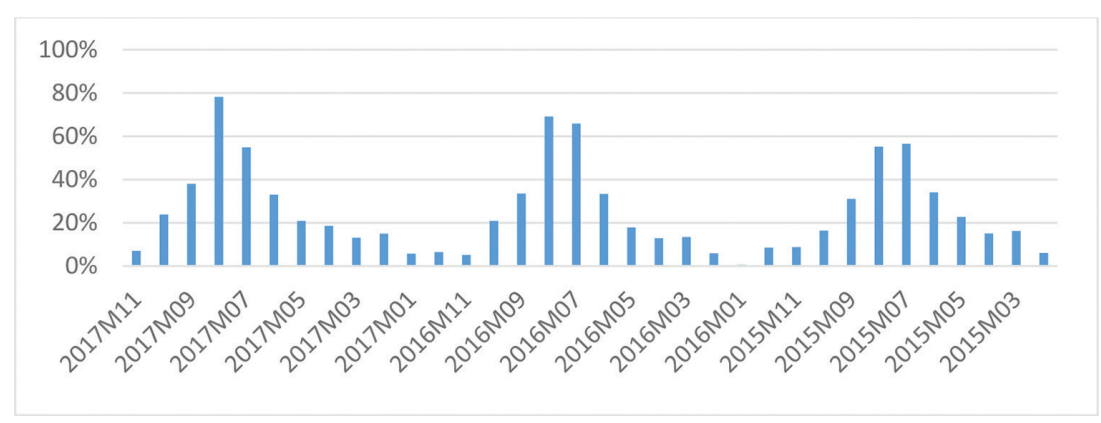

Figure 1: Denia. Occupancy rate of apartment. (Source: Authors, based on INE data) 
Table 5: Denia and Torrevieja. Employment rate in construction.

\begin{tabular}{lll}
\hline Employed in construction & Denia & Torrevieja \\
\hline 2011 & 11,07 & 6,89 \\
2001 & 19,29 & 19,98 \\
1991 & 17,14 & 14,53 \\
\hline
\end{tabular}

(Source: Authors, based on data from ARGOS)

Table 6: Spain and Torrevieja. Unemployment rate and households' yearly average income.

\begin{tabular}{lllll}
\hline & \multicolumn{2}{l}{ Unemployment rate $(\%)$} & \multicolumn{2}{l}{ Households' yearly average income } \\
\cline { 2 - 5 } & Spain & Torrevieja & Spain & Torrevieja \\
\hline 2016 & 19,63 & 22,63 & 26.730 &.. \\
2015 & 22,06 & 25,27 & 26.092 &.. \\
2014 & 24,44 & 25,97 & 26.154 & $14.461,67$ \\
2013 & 26,09 & 26,97 & 26.775 & $13.977,15$ \\
2012 & 24,79 & 26,18 & 27.747 & $13.870,91$ \\
2011 & 21,39 & 23,29 & 28.206 & $14.490,85$ \\
2010 & 19,86 & 24,01 & 29.634 &.. \\
\hline
\end{tabular}

(Source: Authors, based on data from INE)

Table 6 clearly shows how the bursting of the housing bubble has led to more negative impacts on employment and income in Torrevieja than in the whole of Spain.

The described impacts generate in turn other effects derived from the weaknesses and inefficiencies of the model which eventually highlights its unsustainability. RT is characterized by its rapid urban growth, its extensive morphological configuration and the lack of control and urban planning. The territorial expansion of RT generates serious environmental impacts, related to the excessive consumption of land and water resources [23]. Specifically, the amount of developable land required by the RT model ends up exhausting the available urban land, jeopardizing and eventually preventing the future expansion of the model. This reliance on real estate activity compromises the socioeconomic future both of the public and private sector in RT municipalities [3].

The economic ripples triggered by the RT model have long term consequences for they have kept exerting an impact on the territory even after the construction frenzy ground to a halt as a result of the crisis. The solidification of these impacts turns them into factors of vulnerability for local communities, generating significant amounts of risk. In this sense, risk is understood as the result of the combination of a threat (bursting of the bubble) and a vulnerable group (local community). This structural vulnerability seriously hampers the finding of alternatives that could trigger the necessary changes to economically and socially overcome the RT model [19]. Box 1 below summarizes the vulnerability factors associated to RT. 


\begin{tabular}{|c|c|}
\hline \multicolumn{2}{|r|}{ Box 1. Vulnerability factors of RT. } \\
\hline Vacant dwellings & $\begin{array}{l}\text { - Underutilization of urban infrastructure and services } \\
\text { - Loss of value of real estate assets because they are out of } \\
\text { the market }\end{array}$ \\
\hline Seasonality & $\begin{array}{l}\text { - Strain on infrastructures and supply of urban services } \\
\text { during high season. } \\
\text { - Underutilization of services in low season } \\
\text { - Unemployment increase in low season } \\
\text { - Low quality of employment } \\
\text { - Discouraging of implementation of other type of eco- } \\
\text { nomic activity and businesses }\end{array}$ \\
\hline $\begin{array}{l}\text { Dependence on construc- } \\
\text { tion }\end{array}$ & $\begin{array}{l}\text { - Scarcity/depletion of developable land } \\
\text { - High environmental impacts } \\
\text { - Unemployment in times of real estate crisis }\end{array}$ \\
\hline Unstructured offer & $\begin{array}{l}\text { - Lack of transparent offer } \\
\text { - Hinders tax collection } \\
\text { - Unstructured offer hampering the process of real state } \\
\text { consumption } \\
\text { - Loss of income for the owners }\end{array}$ \\
\hline (Source: Authors) & \\
\hline
\end{tabular}

\section{RESULTS AND DISCUSSION}

The recent phenomenon of $\mathrm{P} 2 \mathrm{P}$ platforms for tourist accommodation is in continuous growth $[7,10-12]$ and calls for the need to harmoniously integrate these platforms with the traditional offer. The chart below shows the evolution of this kind of accommodation in Denia and Torrevieja.

The significant increase in accommodation available on the Airbnb platform in recent years shows the potential of this phenomenon. We have jumped from only 7 and 9 accommodations in Denia and Torrevieja in 2011, respectively, to more than 3,000 per municipality at the beginning of 2018 .

His trend, together with the important DPTU stock available in RT municipalities, places these platforms as fundamental players in the use of available real estate assets. In turn, channeling this offer through the P2P-VR platforms can help bring together and visualize a historically unstructured product that was so far rather difficult to market.

The dependence of residential tourism on real estate activity, together with the bursting of the sector bubble, has made the negative impacts of the model more visible. The unemployment rate has increased and household incomes have dropped, increasing the vulnerability of local communities. Given this context, the use of available real estate assets can generate extra income for households and, thus, have a positive impact on the economic activity of the RT municipalities. The following table shows figures referring to number of rented dwellings, the average daily rate per accommodation and the average income obtained per accommodation in the month of January 2018.

The difference between the average rate of Denia and Torrevieja is due to Denia historically having a tourist demand from the Valencian and Madrid bourgeoisie with a higher 


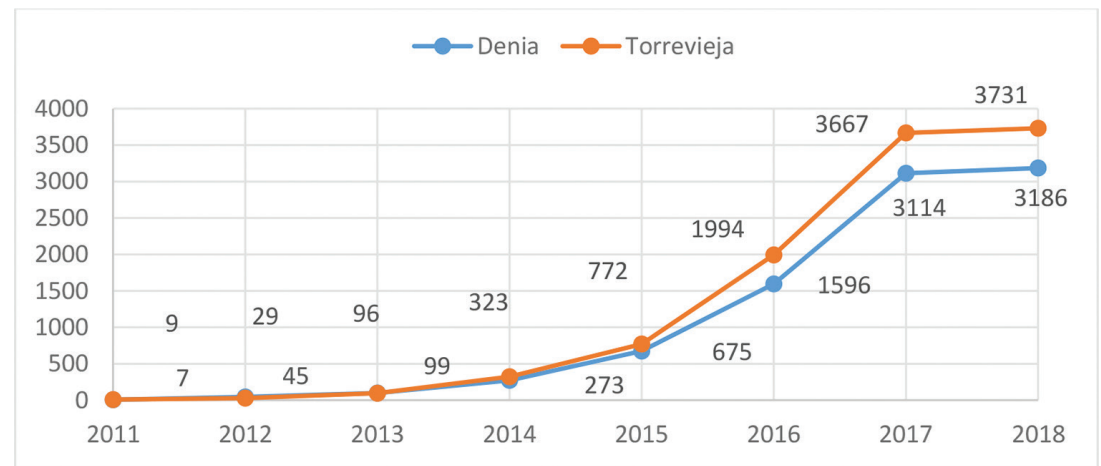

Figure 2: Airbnb accommodation offer per year. (Source: Authors, based on data from AirDNA)

Table 8. Rents, daily rate, monthly income. Airbnb, January 2018.

\begin{tabular}{llll}
\hline & $\begin{array}{l}\text { Rented } \\
\text { dwellings }(\square)\end{array}$ & $\begin{array}{l}\text { Average daily rate per } \\
\text { accommodation }(\square)\end{array}$ & $\begin{array}{l}\text { Average monthly income per } \\
\text { dwelling }(\square)\end{array}$ \\
\hline Denia & 1.818 & 91 & 768 \\
Torrevieja & 2.026 & 49 & 270 \\
\hline
\end{tabular}

(Source: Authors, based on data from AirDNA)

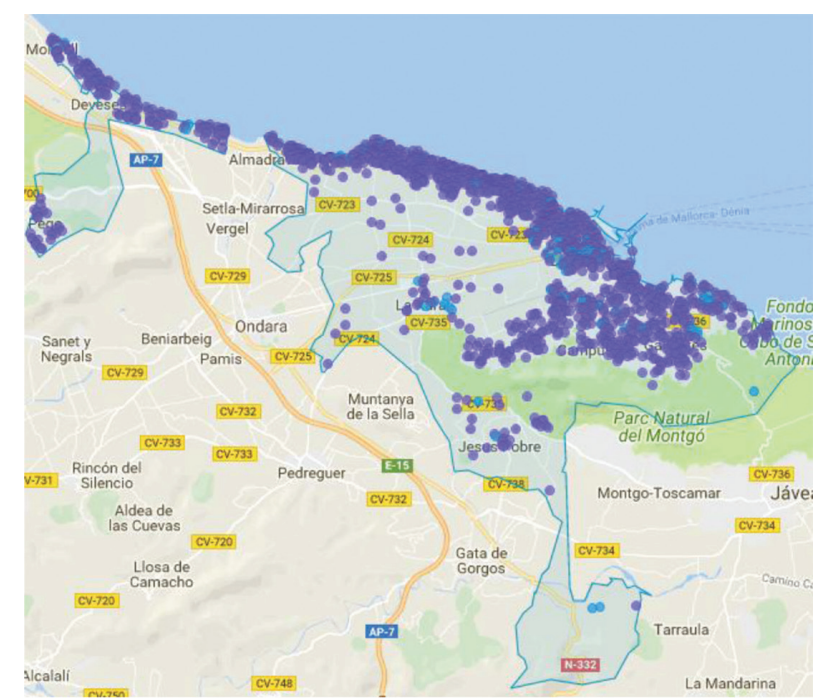

Map 1: Location of Airbnb accommodations in Denia (Source: AirDNA)

purchasing power than the average holidaymaker. That historical trend has found a continuation in the Airbnb model.

The marketing of the DPTU stock through P2P-VR platforms can help reduce the structural seasonality of the RT model and, in turn, favor the use of underutilized urban 


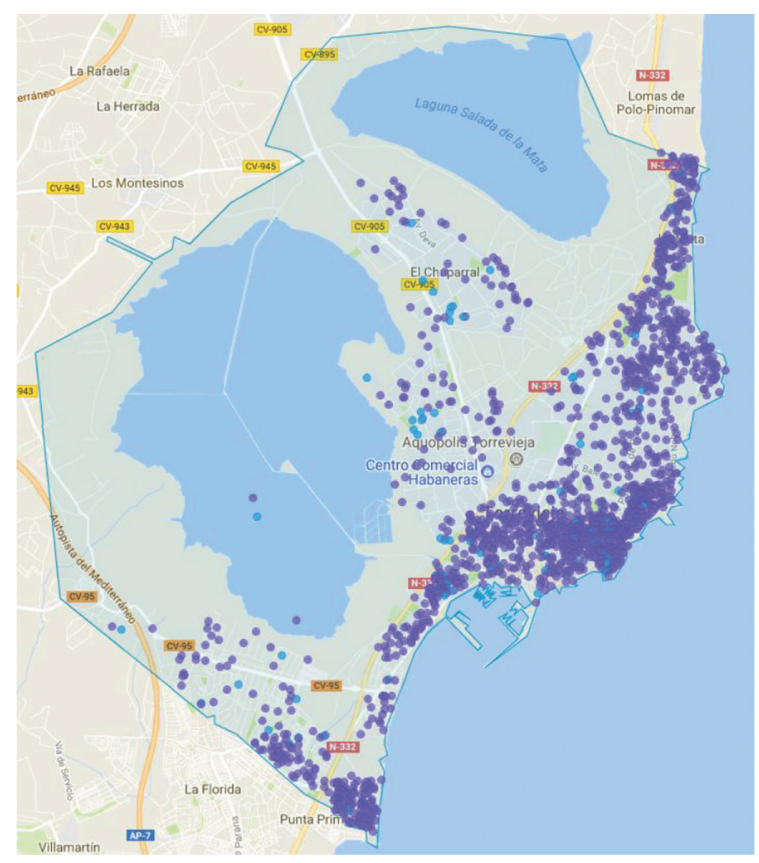

Map 2: Location of Airbnb accommodations in Torrevieja. (Source: AirDNA)

\section{Box 2: Effects of the implementation of regulated P2P-HH platforms in residential tourism municipalities.}

\begin{tabular}{|c|c|}
\hline $\begin{array}{l}\text { Increase in dwelling occu- } \\
\text { pancy }\end{array}$ & $\begin{array}{l}\text { - More efficient use of urban infrastructures and ser- } \\
\text { vices } \\
\text { - Maximization of available real estate assets }\end{array}$ \\
\hline Reduction of seasonality & $\begin{array}{l}\text { - Reduction of dependence on high tourist season } \\
\text { - Boost to economy as a whole } \\
\text { - Direct and indirect employment creation }\end{array}$ \\
\hline $\begin{array}{l}\text { Lower dependence on con- } \\
\text { struction }\end{array}$ & $\begin{array}{l}\text { - Reduction of developable urban land consumption } \\
\text { - Minimizing of environmental impacts } \\
\text { - Reactivation of other economic sectors }\end{array}$ \\
\hline More structured offer & $\begin{array}{l}\text { - Regulated and transparent offer for the regulating } \\
\text { and tax collecting bodies } \\
\text { - Compact offer, accessible through on line channels } \\
\text { (P2P platforms) } \\
\text { - Additional income for households and improvement } \\
\text { of their purchasing power } \\
\text { - Social and spatial cohesion. Offer better distributed } \\
\text { throughout the territory }\end{array}$ \\
\hline
\end{tabular}


services and infrastructures. In addition, it offers a sustainable alternative to the land consumption that characterizes the RT model, since it leads to a more efficient use of the urban infrastructure reducing, in this way, the environmental impacts. The following maps show the location of available accommodation in January 2018 in the analyzed municipalities.

An efficient management of the aforementioned factors can help minimize the structural vulnerabilities of the RT model. In the same way, a positive impact can be produced in the tourism sector that translates in turn into a boost to the whole economy in the municipalities. These synergies can favor the change of a real estate based economic model into one focused on residentiality. The following box summarizes the main positive impacts that a good management of the P2P-VR model could generate in the RT municipalities.

\section{CONCLUSIONS}

In certain municipalities of the Costa Blanca, the hegemony of RT model makes the development of other tourism models considerably more difficult. There is a certain incompatibility, for instance, between the residential tourism model and the hotel model [24]. In view of this situation, the RT municipalities do not seem to have any other way out of the model than to exploit and maximize their main available asset: the Dwellings for Potential Tourist Use. In the better exploitation of this resource, P2P-VR platforms can play a very important role thanks to their dynamism, ease of access and the ability to bring together a historically unstructured offer. However, the advantages featured by these platforms necessarily involve generating new management/governance formulas so that all stakeholders involved can benefit: the public administrations, the construction and real estate sector, the tourism sector, the platforms themselves as well as the owners and customers/holidaymakers.

On the other hand, RT model is based on excessive consumption of urban developable land and is subject to cyclical crises [25]. Faced with the depletion of this resource, the construction-real estate sector has the choice to move to other locations, but territories and its inhabitants do not have the same flexibility to protect themselves from the economic downturns: impacts remain in the local economies for a long time, directly affecting communities and hindering socioeconomic alternatives [26]. With the burst of the housing bubble the unemployment rate has skyrocketed and household incomes dramatically decreased [3]. Therefore, a change of the economic model, favored by adequate management/governance strategies and aiming at reducing the structural vulnerabilities of RT and at strengthening the resilience of local communities is absolutely necessary.

Given the aforementioned characteristics of the RT municipalities and the potentialities identified in the P2P-VR platforms, it is considered that an adequate combination of both can favor the transition from a construction-based economy to a residential one. This turn towards residential development will necessarily involve an overall strategy for urban and tourist development, one that maximizes the use of available resources and a complementary offer. Niche tourism such as golf, nautical and gastronomical tourism, to name just a few, a more sophisticated cultural offer and a sustainable exploitation of the spaces of high environmental value must be linked to the adequate regulation of the P2P-VR activity in these municipalities. This set of strategies, in turn, can help to create positive synergies in different sectors and, in short, help the economic revitalization of some municipalities that have relied heavily on the construction of second homes. 


\section{REFERENCES}

[1] Gutiérrez, J., García-Palomares, J.C., Romanillos, G. \& Salas-Olmedo, M.H., The eruption of Airbnb in tourist cities: comparing spatial patterns of hotels and peer-topeer accommodation in Barcelona. Tourism Management, 62, pp. 278-291, 2017.

https://doi.org/10.1016/j.tourman.2017.05.003

Aledo, A., Ortiz, G. \& García-Andreu, H., Análisis estructural del sistema turístico residencial de la Costa Blanca. Investigaciones Geográficas, (46), pp. 89-106, 2008. https://doi.org/10.14198/ingeo2008.46.05

[2] García-Andreu, H., El círculo vicioso del turismo residencial: análisis de los factores locales del boom inmobiliario español. PASOS Revista de turismo y patrimonio cultural, 12(2), pp. 395-408, 2014.

https://doi.org/10.25145/j.pasos.2014.12.028

[3] Botsman, R. \& Rogers, R., What's Mine is Yours: The Rise of Collaborative Consumption, Harper Business, New York, 2010.

[4] Guillén Navarro, N.A. \& Iñiguez Berrozpe, T., Acción pública y consumo colaborativo. Regulación de las viviendas de uso turístico en el contexto P2P. PASOS Revista de turismo y patrimonio cultural, 14(3), pp. 751-768, 2016.

https://doi.org/10.25145/j.pasos.2016.14.049

[5] De la Encarnación, A.M., El alojamiento colaborativo: Viviendas de uso turístico y plataformas virtuales. Revista de Estudios de la Administración Local y Autonómica, (5), p. 26, 2016.

https://doi.org/10.24965/reala.v0i5.10350

[6] Zervas, G., Proserpio, D. \& Byers, J.W., The rise of the sharing economy: estimating the impact of Airbnb on the hotel industry. Journal of Marketing Research, 54(5), pp. 687-705, 2017.

https://doi.org/10.1509/jmr.15.0204

[7] Belk, R., You are what you can access: sharing and collaborative consumption online. Journal of Business Research, 67(8), pp. 1595-1600, 2014. https://doi.org/10.1016/j.jbusres.2013.10.001

[8] Cheng, M., Sharing economy: a review and agenda for future research. International Journal of Hospitality Management, 57, pp. 60-70, 2016.

https://doi.org/10.1016/j.ijhm.2016.06.003

[9] Wang, D., Nicolau, J.L., Price determinants of sharing economy based accommodation rental: a study of listings from 33 cities on Airbnb.com. International Journal of Hospitality Management, 62, pp. 120-131, 2017.

https://doi.org/10.1016/j.ijhm.2016.12.007

[10] Guttentag, D., Airbnb: disruptive innovation and the rise of an informal tourism accommodation sector. Current Issues in Tourism, 18(12), pp. 1192-1217, 2015. https://doi.org/10.1080/13683500.2013.827159

[11] Cañigueral, A., Hacia una economía colaborativa «responsable». Oikonomics: Revista de Economía, Empresa y Sociedad, (6), pp. 16-27, 2016.

[12] Acquier, A., Daudigeos, T. \& Pinkse, J., Promises and paradoxes of the sharing economy: an organizing framework. Technological Forecasting and Social Change, 125, pp. $1-10,2017$.

https://doi.org/10.1016/j.techfore.2017.07.006 
[13] Frenken, K. \& Schor, J., Putting the sharing economy into perspective. Environmental Innovation and Societal Transitions, 23, pp. 3-10, 2017. https://doi.org/10.1016/j.eist.2017.01.003

[14] Rodríguez-Antón, J.M., Alonso-Almeida M del, M., Rubio-Andrada, L. \& Celemín Pedroche, M.S., La economía colaborativa. Una aproximación al turismo colaborativo en España. CIRIEC-España, revista de economía pública, social y cooperativa, (88), pp. 259-283, 2016.

[15] Miralles. P. \& Villar, A., Las viviendas de uso turístico: un análisis del conflicto. International Journal of World of Tourism, 3(6), pp. 22-35, 2016.

[16] Fernández Pérez, N., Turismo P2P o colaborativo. Un reto para el ordenamiento jurídico. International Journal of Scientific Managment Tourism, 2(2), 2016.

[17] Vanclay, F., Conceptual and methodological advances in social impact assessment. The International Handbook of Social Impact Assessment: Conceptual and Methodological Advances, pp. 1-9, 2003.

https://doi.org/10.4337/9781843768616.00011

[18] Aledo, A., Turismo residencial y vulnerabilidad en el interior del Levante español. Turismo residencial y gentrificación rural, ed. El Sauzal (Tenerife): PASOS, pp. 37-60, 2016.

[19] Huete, R., Mantecón, A. \& Mazón, T., ¿De qué hablamos cuando hablamos de turismo residencial? Cuadernos de Turismo, (22), pp. 101-121, 2008.

[20] Mazón, T. \& Huete, R., Turismo residencial en el litoral alicantino: Los casos de Denia, Altea, Benidorm, Santa Pola y Torrevieja. Tur Resid y cambio Soc Nuevas Perspect teóricas y empíricas. CAM, Obras Sociales, pp. 105-138, 2005.

[21] Aledo, A. \& Mazón, T., Los límites del turismo residencial: El caso de Torrevieja. Estud turísticos. Instituto Español de Turismo, (165), pp. 77-95, 2005.

[22] Aledo, A., Garcia, H. \& Ortiz, Y.G., Análisis de mapas causales de impactos del turismo residencial. Empiria. Revista de metodología de ciencias sociales, 20(20), pp. 61-86, 2010. https://doi.org/10.5944/empiria.20.2010.2040

[23] Martínez, F.J., Pauls, A.J. \& Monzonís, J.S., Las viviendas familiares y su uso turístico en la Comunidad Valenciana. Estud Turísticos, (155-156), pp. 159-177, 2003.

[24] Aledo, A., De la tierra al suelo: La transformación del paisaje y el nuevo turismo residencial. Arbor Ciencia, pensamiesnto y Cult. Consejo Superior de Investigaciones Científicas, (729), pp. 99-113, 2008.

[25] Aledo, A., Loloum, T., Ortiz, G. \& García-Andreu, H., El turismo residencial internacional en el nordeste de Brasil / International Residential Tourism on the Northeast of Brazil. Revista Española de Investigaciones Sociológicas, 2013. 